\title{
因putthp Balfighund?.
}

Bon

\section{Elard Gqugo $\mathfrak{i}$ eyer.}

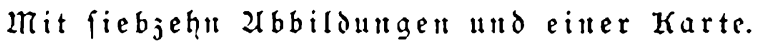

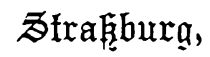

$\mathfrak{B e r l a g}$ von $\mathfrak{T} \mathfrak{a} \mathfrak{l} \mathfrak{\mathfrak { S }}$. Trübuer.

1898. 
Alle Redte, insbejondere bas ber überietung, vorbegalten.

Truf von żifher \& Bittig in Leipzig. 